\title{
Table of documents and instruments: International and national law and policy instruments, CSR and BHR instruments, organisation documents and stakeholder statements
}

\section{INTERNATIONAL INSTRUMENTS (HARD LAW, SOFT LAW, POLICY INSTRUMENTS)}

\section{Council of Europe}

European Convention on Human Rights (ECHR) 145,155

European Social Charter, Council of Europe (1961),

ETS No. 35 $145,150,152,155$

European Social Charter (Revised), Council of Europe (1996), ETS No. 163 145,150 , 152,155

\section{European Union (EU)}

Commission of the European

Communities (2001)

Promoting a European

Framework for Corporate

Social Responsibility

COM(2001)366 50,144 $145,146,147,148,303$

Commission of the European

Communities (2002)

Corporate Social

Responsibility: A business

contribution to sustainable

development COM(2002)347 ..... 49, $144,145,148-150,303,306$
Commission of the European

Communities (2006)

Communication from the

Commission to the European

Parliament, the Council and

the European Economic and

Social Committee:

Implementing the Partnership

for Growth and Jobs. 144,145 , $165,170,303,306,324$

Annex.... 165, 166, 170, 171, 270, 306

Directive 2014/95/EU Non-

Financial Reporting, OJ 2014

L 330

$47,57,211,265$

European Commission (2011)

Communication on a renewed

EU Strategy 2011-14 for

Corporate Social

Responsibility 265,325

European Parliament (1999)

Resolution on EU standards

for European enterprises

operating in developing

countries: towards a European

Code of Conduct, OJ C

104/180, EP Resolution

A4-0508/98, adopted on 15

January.

European Parliament (1999)

Resolution on the

Communication from the

Commission to the Council on

the trading system and 
internationally recognised

labour standards

(COM(96)0402 - C4048896),

A4-0423/98, adopted on 13

January, OJ 1999 C104/63, 14

April.

143,144

Lisbon Goals (Council of the

European Union (2000)

Presidency conclusions,

Lisbon European Council, 23

and 24 March 2000). 144,145 , $146,166,167$

Regulation (EC) No 2173/2005

of 20 December 2005 on the establishment of a FLEGT licensing scheme for imports of timber into the European Community, EU doc. OJ 2005

L 347/1

Regulation (EU) 995/2010 of

20th October 2010 Timber

Regulation - obligations of operators who place timber and timber products on the market, EU doc. OJ 2010 L $295 / 23$

Transparency Directive (2013/50/ EU) .47

Treaty on the Functioning of the European Union, TFEU, 2009 (Lisbon Treaty). 145

\section{International Labour Organisation (ILO)}

ILO Constitution, adopted by the Peace Conference April 1919, 15 UNTS 40 114

ILO Convention No. 29, Forced Labour Convention (1930) 39 UNTS 55 ..... . $9,68,99$

ILO Convention No. 87, Freedom of Association and Protection of the Right to Organise Convention (1949) 68 UNTS 17. $9,68,99$

ILO Convention No. 98, Right to Organise and Collective Bargaining Convention (1949) 96 UNTS 257 9, 68, 99
ILO Convention No. 100, Equal Remuneration Convention (1951) 165 UNTS 303. $9,68,99$

ILO Convention No. 105, Abolition of Forced Labour Convention (1957) 320 UNTS

291 $6,68,99$

ILO Convention No. 111,

Discrimination (Employment and Occupation) Convention (1958) 362 UNTS 31 $9,68,99$

ILO Convention No. 138, Minimum Age Convention (1973) 1015 UNTS 297. $9,68,99$

ILO Convention No. 182, Worst Forms of Child Labour Convention (1999) 2133 UNTS 161 $9,68,99$

ILO Declaration on Fundamental Principles and Rights at Work (1988), 37 ILM 1233 ... 73, 112, 113, 132, $136,149,155,156,171,217,302$ Art 2 .

ILO Fundamental conventions ......143, $148,149,150,151,152,155,169$, 174, 241, 261, 279, 281, 287, 298, $302,313,314,320$

ILO Tripartite Declaration of Principles concerning Multinational Enterprises and Social Policy (MNE

Declaration, 1977).....35, 42, 73, 112, $113,114,115,119,121,129,143$, $144,155,156,179,188,217,279$,

290

\section{United Nations (UN)}

Commission on Human Rights (2006) Interim report of the Special Representative of the Secretary-General on the issue of human rights and transnational corporations and other business enterprises, UN Doc. E/CN.4/2006/97, 22

February 194, 293

Framework Convention on

Climate Change 1992 .75 
Human Rights Council (2008)

Corporations and human

rights: a survey of the scope

and patterns of alleged

corporate-related human

rights abuse, UN Doc. A/

HRC/8/5/Add.2, 23 May

Human Rights Council (2008)

Clarifying the concepts of

"Sphere of Influence" and

"Complicity", UN Doc. A/

HRC/8/16, 15 May 234,295

Human Rights Council (2008)

Mandate of the Special

Representative of the

Secretary-General on the issue

of human rights and

transnational corporations

and other business enterprises,

Human Rights Council

Resolution, 8/7June

242,252

Human Rights Council (2009)

Business and human rights:

Towards operationalizing the "protect, respect and remedy"

framework, Report of the

Special Representative of the

Secretary-General on the issue

of human rights and

transnational corporations

and other business enterprise,

UN Doc. A/HRC/11/13, 22

April.

Human Rights Council (2010)

Business and human rights:

Further steps toward the

operationalization of the

"protect, respect and remedy"

framework', Report of the

Special Representative of the

Secretary-General on the issue

of human rights and

transnational corporations

and other business enterprises,

John Ruggie, UN Doc. A/

HRC/14/27, 9 April

Human Rights Council (2014)

Elaboration of an

international legally binding

instrument on transnational .254 corporations and other

business enterprises with

respect to human rights, $\mathrm{UN}$

Doc. A/HRC/RES/26/9, 14

July.

88,262

International Bill of Human

Rights (UDHR, ICESCR,

ICCPR)

.. $9,155,165$,

$174,241,281,298,313,314,320$

International Covenant on

Economic, Social and Cultural

Rights (ICESCR) .....9, 143, 145, 155

International Covenant on Civil and Political Rights (ICCPR) ........ 9, 143,155

K. Annan (1999), Address of

Secretary-General Kofi Annan

to the World Economic

Forum in Davos, Switzerland,

31 January 134,139 , 284, 286, 287, 298

Paris Climate Change Accord 2015 $4,13,325,326$

Rio Declaration on Environment and Development, UN Doc. A/CONF.151/26 (Vol. I), 12 August 1992 ..........42, 121, 132, 136

Rome Statute of the International Criminal Court, adopted by the UN General Assembly on 17 July1998, UN

Doc. A/Conf.183/9 22,222

Sustainable Development Goals

(SDGs). $13,15,326$

Treaty on the Non-Proliferation of Nuclear Weapons.................... 11

UN Charter (1945), UNTS 993....... 97, 198, 204, 298, 301, 321

Preamble .................................... 15

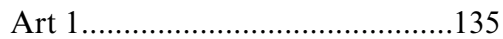

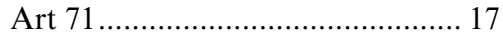

UN Commission on Human

Rights (2005) Human rights

and transnational corporations and other business enterprises

(resolution).....

UN Commission on Human

Rights (2006) Interim report

of the Special Representative 
of the Secretary-General on the issue of human rights and transnational corporations and other business enterprises, UN Doc. E/CN.4/2006/97, 22 February 2006(SRSG 2006 (Interim) Report) 186-202

UN Convention against Corruption, UN Doc. A/58/422, 31 October 2003 132

UN Convention on the Rights of Persons with Disabilities, December 2006. 150

UN Declaration of the Right to Development (1986), UN Doc. A/RES/41/218, 4 December. 72

UN Declaration on the Rights of Indigenous Peoples, UN Doc. A/61/L.67, 13 September 2007 .73, 231

UN Draft Code of Conduct on Transnational Corporations. Development and International Economic Cooperation: Transnational Corporations, UN Doc. E/1990/ 94, 12 June 1990 8,73 $111,112,114,115,116,131,170$,

UN 'Protect, Respect and 251

Remedy' Framework (UN Framework), Report of the Special Representative of the Secretary General on the issue of human rights and transnational corporations and other business enterprises, John Ruggie, UN Doc. A/ HRC/8/5, 7 April 2008 . 6-9, 10, $11,12,13,20,25,35,36,38,39,40$, $42,45,47,48,53,58,68,88,89,95$, $96,101,102,105,106,123,124$, $125,126,145,168,171,172,173$, 174, 175, 176-226, 228, 229, 231, 232, 233-243, 244, 246, 247, 248, 249, 251, 252-256, 260, 261, 262, 264, 265, 270, 271, 275, 276, 280, 281, 282, 284, 285, 288-298, 303, $304,306,307,308,309,312,313$,
$314,316,318,319,320,321,322$, $324,325,328,329,331$

UN General Assembly, Towards global partnerships: Resolution adopted by the General Assembly, UN Doc. A/RES/55/215, passed 21 December 2000 73,137

UN General Assembly, Towards global partnerships: Resolution adopted by the General Assembly, UN Doc. A/RES/56/76, passed 11 December 2001 $.73,137$

UN General Assembly, Towards global partnerships: Resolution adopted by the General Assembly, UN Doc. A/RES/58/129, 19 December 2003

UN General Assembly, Towards global partnerships: Resolution adopted by the General Assembly [on the report of the Second Committee (A/60/495 and Corr.1)], UN Doc. A/ RES/60/215/, 29 March 2006 (passed 22 December 2005) ...73, 137

UN Global Compact 15,19 , 20, 34, 36, 39, 42, 44, 51, 52, 63, 73, $96,102,105,106,113,118,119$, $123,128,129,131-142,146,147$, $150,155,156,159,163,171,179$, $192,244,250,270,278,279,283$, 284, 285, 286, 287, 293, 297 , 298-302, 303, 304, 308, 312, 313, $316,318,322,324,329$

Principles 1-2, Human rights .....131, 278,323

Principle 2 ...............................123

Principles 3-6, Labour rights......113, $131,278,323$

Principle 3 .223

Principles 7-9, Environment.......131, 278

Principle 10, Anti-corruption .....132, 278

UN Guiding Principles

(UNGPs), Human Rights 
Council (2011) Guiding

Principles on Business and

Human Rights: Implementing

the United Nations 'Protect,

Respect, Remedy' Framework,

Report of the Special

Representative of the

Secretary-General on the issue

of human rights and

transnational corporations

and other business enterprises.

UN Doc. A/HRC/17/31, 21

March 6-9, 11, 12, 13,

$20,35,49,57,88,96,105,106,115$, $123,124,172,173,174,175,184$, 204, 211, 223, 243, 251, 252-256, $260,261,262,265,271,275,276$, 280, 281, 282, 289, 298, 312, 313, $314,319,320,321,325,326$

UN High Commissioner for Human Rights/Commission on Human Rights (2005) Report on Human Rights and the extractive industry, 10-11 November, UN Doc. E/ CN.4/2006/92, 19 December 189

UN High Commissioner for Human Rights/Commission on Human Rights (2007)

Report on Human Rights and the Financial Sector, 16

February, UN Doc. A/ HRC/4/99, 6 March. .215

UN Human Rights Council (2007) Business and Human Rights: Mapping international standards of responsibility and accountability for corporate acts, Report of the SRSG on the issue of human rights and transnational corporations and other business enterprises (SRSG 2007 Report), UN Doc. A/ HRC/4/35, 9 February....... 202-243,

UN Millennium Declaration..... 42, 121 UN Millennium Development Goals (MDG). 195
UN Sub-Commission on Prevention of Discrimination and Protection of Minorities (1995) The realization of Economic, Social and Cultural Rights: The relationship between the enjoyment of human rights, in particular, international labour and trade union rights, and the working methods and activities of transnational corporations, UN Doc. E/CN.4/

Sub.2/1995/11, 24 July 116

UN Sub-Commission on Prevention of Discrimination and Protection of Minorities (1996) The impact of the activities and working methods of Transnational Corporations on the full enjoyment of human rights, in particular Economic, Social and Cultural Rights and the Rights to Development, Bearing in mind existing international guidelines, rules and standards relating to the subject matter, UN Doc. E/ CN.4/Sub.2/196/12, 2 July..

UN Sub-Commission on Prevention of Discrimination and Protection of Minorities (1998) The realization of Economic, Social and Cultural Rights: The Question of Transnational Corporations, UN Doc. E/CN.4/Sub.2/198/6, 10 June

UN Sub-Commission on the Promotion and Protection of Human Rights (1998)

Resolution, 1998/8, 20 August 1998

UN Sub-Commission on the Promotion and Protection of Human Rights (2003) Norms on the Responsibilities of Transnational Corporations and Other Business 
Enterprises with regard to

Human Rights, UN Doc. E/

CN.4/Sub.2/2003/12/Rev.2

(Draft Norms)........8, 19, 20, 34, 35, $36,38,39,73,96,102,105,116$ $131,132,133,134,137,146,168$, $169,170,173,175,176-185,186$, 187, 191, 196, 198, 200, 204, 205, $208,210,211,218,222,231,233$, $233,239,244,245,246,248,254$, $273,276,278,280,282,284,285$, 288-298, 302, 306, 307, 308, 318, $319,321,322,327,328$

Preamble $42,121,122$

Universal Declaration on

Human Rights (UDHR) 9, 10, 68, 71, 99, 121, 122, 132, $136,155,156,171,195,298,302$

World Summit on Sustainable

Development, Plan of

Implementation,

Johannesburg (2002) $42,63,121$

\section{Organisation for Economic \\ Collaboration and Development (OECD) \\ OECD Declaration on}

International Investment and

Multinational Enterprises

113,114

OECD Guidelines for

Multinational Enterprises.......35, 42, $112,113,114,115,119,121,128$, $129,143,144,147,148,149,150$, $152,155,156,159,169,179,188$, $217,229,234,240,265,279,287$,

290,325

\section{Other}

Maastricht Guidelines on

Violations of Economic,

Social and Cultural Rights 187

\section{NATIONAL LEGISLATION}

\section{China}

Labour Contract Law 2007 56

\section{Denmark}

Act on Financial Statements 2008

\section{India}

Companies Act, 2013 revision

Art 135(5)....

\section{United States}

Alien Torts Statute, 28 U.S.C. § 1350 (Alien Torts Claims Act) ....110, 111,193

Dodd-Frank Wall Street Reform Act 2010

s 1502

s 1504

Lacey Act, 16 U.S.C. § 33713378

\section{CSR AND BHR INSTRUMENTS (PRIVATE, PUBLIC AND HYBRID)}

Equator Principles 108

EU CSR Alliance (2006-08) ........... 35, $36,39,42,96,105,164-168,169$, $170,276,278,279,280,283,285$, 287, 302-306, 307, 308, 312, 313, $316,318,322,324,329$

EU Multi-stakeholder Forum

(MSF) on CSR ............... 34, 35, 36, $39,42,96,105,106,142-164,165$, 166, 191, 208, 209, 276, 277, 278, $279,280,283,284,285,286,287$, 298, 302-306, 307, 308, 311, 312, $313,316,318,319,322,327,328$, 329,331

Forest Stewardship Council

(FSC), Principles .......................... 51

Global Reporting Initiative, GRI .... 48, 51

ISO 26000 Social Responsibility

(SR) Guidance Standard 41 , 51,325 207, 217 
SA8000 (Social Accountability

International) 51

Principles for Responsible Investment (PRI) 63 ,

108

Programme for the Endorsement of Forest Certification

(PEFC) $.51-52$

OECD Declaration on International Investment and Multinational Enterprises. 112 113,114

OECD Guidelines for

Multinational Enterprises. .. 35, $42,112,113,114,115,119,121$, $128,129,143,144,147,148,149$, $150,152,155,156,159,169,179$, $188,217,229,234,240,265,279$, 287, 290, 325

Voluntary Principles on Business and Human Rights. 207,217

UN Framework: UN Protect,

Respect and Remedy

Framework, Report of the

Special Representative of the

Secretary General on the issue of human rights and transnational corporations and other business enterprises, John Ruggie, UN Doc. A/

HRC/8/5, 7 April 2008 6-9, $10,11,12,13,20,25,35,36,38,39$, $40,42,45,47,48,53,58,68,88,89$, $95,96,101,102,105,106,123,124$, $125,126,145,168,171,172,173$, $174,175,176-226,228,229,231$, 232, 233-243, 244, 246, 247, 248, 249, 251, 252-256, 260, 261, 262, $264,265,270,271,275,276,280$, 281, 282, 284, 285, 288-298, 303, 304, 306, 307, 308, 309, 312, 313, $314,316,318,319,320,321,322$, $324,325,328,329,331$

UN Global Compact 15,19 , $20,34,36,39,42,44,51,52,63,73$, 96, 102, 105, 106, 113, 118, 119, $123,128,129,131-142,146,147$, $150,155,156,159,163,171,179$, 192, 244, 250, 270, 278, 279, 283, 284, 285, 286, 287, 293, 297 ,
298-302, 303, 304, 308, 312, 313, $316,318,322,324,329$

Principles 1-2, Human rights .....131, 278,323

Principle 2 ...................................123

Principles 3-6, Labour rights......113, $131,278,323$

Principle 3 .223

Principles 7-9, Environment.......131, 278

Principle 10, Anti-corruption .....132,

UN Guiding Principles 278

(UNGPs), Human Rights

Council (2011) Guiding

Principles on Business and

Human Rights: Implementing

the United Nations 'Protect,

Respect, Remedy' Framework,

Report of the Special

Representative of the

Secretary-General on the issue of human rights and transnational corporations and other business enterprises. UN Doc. A/HRC/17/31, 21

March 6-9, 11, 12, 13, $20,35,49,57,88,96,105,106,115$, $123,124,172,173,174,175,184$, $204,211,223,243,251,252-256$, $260,261,262,265,271,275,276$, 280, 281, 282, 289, 298, 312, 313, $314,319,320,321,325,326$

\section{ORGANISATIONAL DOCUMENTS AND STAKEHOLDER STATEMENTS}

Amnesty International (2005) Letter to Professor John Ruggie, AI ref UN 260-2005, 16 September 187-188, 291

Amnesty International (2006) Letter to John Ruggie, 27 April. .247

Amnesty International (2005)

Statement, UN Commission 
on Human Rights: The UN's chief guardian of human rights? January $178,179,290$

Amnesty International (2005)

Statement, UN Commission on Human Rights: Amnesty International welcomes new UN mechanism on Business and Human Rights, April.... 182, 186

Asian civil society statement to UN Special Representative on transnational business and human rights at the Asia Regional Consultation, Bangkok, Thailand, 27 June 2006 .211

CIDSE - Développement et la

Solidarité, (2008) Submission to the Special Representative of the United Nations

Secretary-General on Business and Human Rights:

Recommendations to reduce the risk of human right violations and improve access to justice, February.......228, 258, 309

Clean Clothes Campaign (2007) Letter to John Ruggie, Amsterdam, 23 March 228 258,309

ESCR-Net Corporate Accountability Working Group (2005) Joint NGO submission: Consultation on human rights and the extractive industry, final version 9 December......190, 191, 290

FIDH (2006) 'Position paper:

Comments to the interim report of the Special Representative of the Secretary-General on the issue of Human Rights and Transnational Corporations and other business enterprises, February 22, 2006', 15 March ...203204, 205, 225, 246

Forest Peoples Programme and Tebtebba Foundation (2006), Indigenous Peoples' rights, extractive industries and transnational and other enterprises: A submission to the Special Representative of the Secretary-General on human rights and transnational corporations and other business enterprises, 29 December ..................................203

Human Rights Watch and others (2006) Joint NGO letter in Response to Interim Report 1 ....205

Interfaith Center for Corporate Responsibility (2006) Letter to John Ruggie, 6 February . 191,

Interfaith Center on Corporate Responsibility (2006) Letter to John Ruggie, 10 October .... .213

International Chamber of Commerce and International Organisation of Employers (2003), Joint views of ICC and the IOE on the draft Norms on the Responsibilities of Transnational Corporations and Other Business

Enterprises with regard to Human Rights.

International Commission of Jurists (2005) Corporate Accountability, International human rights law and the United Nations, Geneva, 9 June.

International Council on Mining and Metals (ICCM) (2006) Submission to UN Secretary General's Special Representative on Human Rights and Business: Clarity and consensus on legitimate human rights responsibilities for companies could accelerate progress, March 2006 ........ 207, 208,

International Council on Mining and Metals (ICMM) (2006) Second submission to UN Secretary General's Special 
Representative on Human Rights and Business: Mining and Human Rights: How the UN SRSG can help spread good practice and tackle critical issues, October International Network for Economic, Social and Cultural Rights (2007) Letter to John Ruggie, 5 September.... 230 International Network for Economic, Social \& Cultural Rights (2007) Letter to John
Ruggie, Joint NGO letter on work of the mandate, 10

October 229,309

IOE, ICC, BIAC (2006) Business and human rights: The role of business in weak governance zones: Business proposals for effective ways of addressing dilemma situations in weak governance zones, Geneva, December 2006. 209,210 $211,225,247,250,254,257,259$, 
Karin Buhmann - 9781786431653

Downloaded from PubFactory at 04/26/2023 11:49:01AM via free access 